\title{
Dispersal and recruitment in streams: evidence from genetic studies
}

\author{
Stuart E. BunN AND Jane M. Hughes \\ Centre for Catchment and In-Stream Research and the Cooperative Research Centre for Tropical \\ Rainforest Ecology and Management, Faculty of Environmental Sciences, Griffith University, \\ Nathan, Queensland, 4111, Australia
}

\begin{abstract}
Analysis of genetic variation among populations of stream invertebrates provides a measure of the consequences of effective dispersal, and can be used to determine the extent of movement within and between streams and to infer the likely mechanisms involved. In our recent studies of rainforest stream invertebrates, we have found considerable genetic differentiation among populations of fully aquatic taxa, indicating limited in-stream movement on a very small scale. Adult flight appears to be the principal mechanism of dispersal for aquatic insects; however, analysis of the genetic structure of larval populations of some species also suggests that in-stream movement is limited to a small spatial scale. Furthermore, detailed analysis of the genetic structure of larval populations suggests that recruitment at the reach scale is the result of only a few adult matings and most likely from oviposition by only a few females. We propose that dispersal capability and the stochastic effects of recruitment are key determinants of observed spatial and temporal variation in community structure in some streams.
\end{abstract}

Key words: Dispersal, recruitment, gene flow, streams, allozyme electrophoresis, stream invertebrates, drift.

Stream and river invertebrates are generally considered to have high dispersal capabilities and, given the extensive geographic distributions of some species, it is apparent that effective mechanisms for dispersal do exist, or at least have existed in the past (e.g., Wallace 1990, Mackay 1992). The rapid recovery of stream benthic communities from disturbance also supports this view (Reice 1985, Boulton et al. 1988, Resh et al. 1988, Lake et al. 1989). However, it is worth noting that most manipulative experiments are rarely undertaken at the stream or whole-reach scale and are likely to overestimate the importance of small-spatial-scale recolonisation by crawling or swimming, movement through the hyporheos, and drift. Descriptive studies of recolonisation from large-scale natural disturbances, show that recovery may be much slower (Mackay 1992).

There is little argument that adult flight and downstream drift represent the principal mechanisms of dispersal available to stream and river invertebrates (Williams and Hynes 1976, Müller 1982, Minshall and Petersen 1985, Mackay 1992, Palmer et al. 1996). There is, however, considerable debate over the importance of each of these mechanisms to the maintenance of stream populations (Wilzbach and Cummins 1989, Hershey et al. 1993, Williams and Williams 1993, Anholt 1995). Furthermore, there are obvious limitations to movement that are associated with the unidirectional flow of water and the hierarchical structure of the channel network (Meffe and Vrijenhoek 1988).

Because of the small body size and great abundance of stream benthic invertebrates, only a few direct measures of the distances moved by drift, crawling, swimming, and adult flight have been made (e.g., Freilich 1991). Direct studies of movement, using drift nets and directional traps (e.g., Benson and Pearson 1987, Williams and Hynes 1976, Williams and Williams 1993) or observation (Hynes 1970, Lee and Fielder 1979, Ryan and Choy 1990), have clearly demonstrated that vast numbers of invertebrates move past a fixed point. However, the overall net distance moved during the life time of an individual is less well known. Less conventional techniques using self-marked cases in caddis larvae (Erman 1986), internal tags such as ${ }^{32} \mathrm{P}$ (see Hynes 1970) and, more recently, stable isotope tracers (Hershey et al. 1993) have provided some of the most direct measures of actual distances moved in the long term.

An alternative approach to direct methods is to consider the consequences of dispersal to the genetic structure of populations. If dispersal is high, and thus gene flow is high, we would expect little genetic differentiation among populations (Slatkin 1985). In contrast, if dispersal is 
restricted by barriers and/or low because of poor dispersal abilities of the species in question, differentiation among populations will occur due to natural selection and/or random genetic drift (Slatkin 1985). Analysis of the genetic structure of populations can, therefore, be used to infer the extent and potential mechanisms of dispersal (e.g., Sweeney et al. 1986, 1987, Waples 1987, Zera 1987, Jackson and Resh 1992).

In this paper, we draw largely on our recent published and unpublished work on a range of species of stream invertebrates in small rainforest streams to illustrate how analysis of the genetic structure of populations can be used to answer questions about dispersal in streams. We also provide surprising evidence that recruitment of larval insect populations at the reach scale in these streams is the result of only a few adult matings. These data suggest that population level processes, such as dispersal and recruitment, can have a profound influence on the structure and dynamics of stream communities.

\section{Study Area}

The Conondale Range forms part of the catchment divide separating the Brisbane River and Mary River in southeast Queensland, Australia. The climate of this region is described as subtropical, with hot wet summers and cool dry winters with a mean annual rainfall of approximately $1500 \mathrm{~mm}$ (Australian Bureau of Meteorology 1983). The major vegetation types are a mixture of complex notophyll vine forest, wet sclerophyll forest, and dry sclerophyll forest (Czechura 1991). Rainforest is widely distributed in upland areas ( $>500 \mathrm{~m}$ asl) and as riparian vegetation at lower altitudes.

Most of the research reported here has been conducted within the higher altitude 2nd- and 3rd-order tributaries of the Conondale Range (250-600 $\mathrm{m}$ asl). These headwater streams have high slopes $(2-5 \%)$ in the study reaches, and are characterised by an armoured bed of boulders, cobbles, gravel, and areas of exposed bedrock. The streamflow pattern is markedly seasonal, though there is considerable inter-annual variation (Pusey et al. 1993). During the wet season (summer/autumn), intense rain events (sometimes exceeding $400 \mathrm{~mm} /$ day) can cause major disturbances to the stream bed, and tractive forces greater than $20 \mathrm{~kg} / \mathrm{m}^{2}$ have been recorded (Mosisch 1995, Mosisch and Bunn 1997). For much of the year, however, the streams are reduced to a series of discrete but connected pools. Throughout this dry winter and spring period, the wetted area of the streams is only a small proportion of the active channel width. Further details of the study area and streams can be found in Hughes et al. (1995) and Mosisch and Bunn (1997).

\section{Methods}

We have studied the genetic structure of populations of a range of species of stream invertebrates that are likely to differ in their ability to disperse. These include the small glass shrimp Paratya australiensis (Decapoda:Atyidae), larvae of an undescribed species of Baetis (Ephemeroptera:Baetidae), the sand-cased larvae of Tasiagma ciliata (Trichoptera:Tasimiidae), and adults of Rheumatometra sp. (Hemiptera: Gerridae). Paratya has a fully aquatic life cycle with a planktonic larval stage (Williams 1977), and is the most conspicuous and abundant macroinvertebrate in the pools of the study streams. Baetis sp. is one of the most common algal grazers in pools and riffles, and is thought to have a short-lived adult stage and highly mobile larvae. Tasiagma ciliata has a longer-lived adult stage than Baetis, and is one of 5 species of sandcased caddis whose relatively sedentary larvae can form dense aggregations on cobbles and boulder surfaces. Rheumatometra sp. is a small wingless gerrid, and is common on the surface of stream pools.

Most of the data described here were collected within the same hierarchical sampling design described by Hughes et al. (1995) and Schmidt et al. (1995). This design includes 2 adjacent drainages (Brisbane and Mary rivers), 2 subcatchments within each drainage (Booloumba and Upper Mary in the Mary River, and Kilcoy and Stony in the Brisbane River), and 3 streams in each subcatchment. In our more recent work, we have also sampled multiple reaches within 1 or more streams to examine fine-scale spatial patterns in genetic structure. For example, 12 of the 19 sites sampled for Baetis larvae in late 1994 were from 4 streams ( 3 from each). Tasiagma larvae were sampled from 4 sites from 1 stream (Bundaroo Creek) on 2 occasions (August 1992 and March 1993).

Where possible, samples of at least 100 individuals of each of the study species were col- 
lected from pools and/or riffles along a single reach $(50-100 \mathrm{~m})$ of the tributary streams. Where multiple reaches were sampled within streams, samples were taken from sites separated by at least $300 \mathrm{~m}$. Samples were sealed in plastic bags and taken to the laboratory in liquid nitrogen, and then stored at $-70^{\circ} \mathrm{C}$ until used for electrophoretic analysis. All electrophoresis was performed on cellulose acetate plates (Titan III, Helena Laboratories, Houston, Texas).

Calculations of allele frequencies and $\mathrm{F}_{\mathrm{ST}}$ values, and tests for deviations from Hardy-Weinberg Equilibrium were made using BIOSYS-1 (release 1.7, Champaigne, New York). $\mathrm{F}_{\mathrm{ST}}$ is a measure of the degree of genetic differentiation that occurs between populations. Values range from 0 , when all populations share the same alleles in the same frequencies, to 1 , where fixed allele differences occur between populations. Further details of the laboratory methods and data analysis are given in Hughes et al. (1995) and Schmidt et al. (1995).

\section{Genetic differentiation among stream populations}

\section{Fully aquatic species}

Hughes et al. (1995) reported enormous differences in genetic structure among populations of Paratya australiensis, with fixed differences between populations from different subcatchments at some loci. Large differences were also found within subcatchments, implying there was little movement between streams. This was a surprising finding, given that Paratya has a planktonic larval stage (Williams 1977). The similar finding of high levels of genetic differentiation among populations of another small atyid species (Caridina zebra) in rainforest streams of the wet tropics of northern Australia (Hughes et al. 1996), adds further strength to the argument that in-stream movement of fully aquatic species of invertebrates such as these small shrimps is limited.

\section{Aquatic insects}

The pattern of genetic differentiation among populations of aquatic insects within the stream hierarchy (Fig. 1) was very different from that reported by Hughes et al. (1995) for Paratya. $\mathrm{F}_{\mathrm{ST}}$ values for Tasiagma within a stream were higher

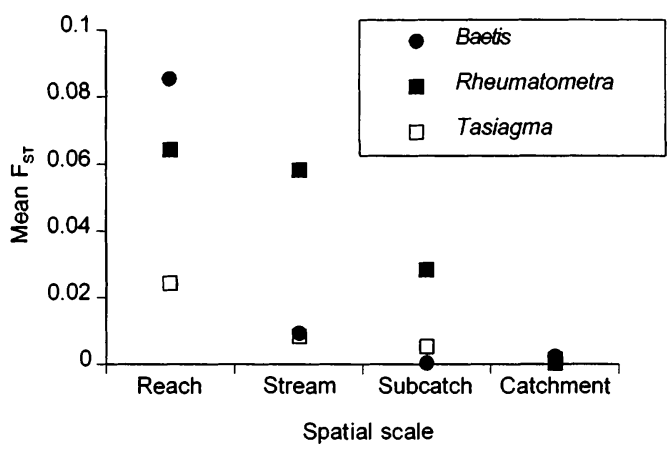

FIG. 1. Jackknife mean $\mathrm{F}_{\mathrm{ST}}$ values for Baetis sp., Rheumatometra sp., and Tasiagma ciliata from rainforest streams in the Conondale Range, plotted at different spatial scales. Mean data are derived from the Brisbane River and Mary River catchments (Catchment), 2 subcatchments within each catchment (Subcatch), 3 streams within each subcatchment (Stream), and up to 4 sites within each stream (Reach).

than at larger spatial scales and were highly significant, which gives the impression that movement must be limited at the within-stream scale. If this result were simply due to limited movement, however, then we would expect to see bigger differences as we move up the spatial hierarchy. This is the case for Paratya, where $\mathrm{F}_{\mathrm{ST}}$ values within stream were similar to those for Baetis and Rheumatometra (Fig. 1) (Mean $\mathrm{F}_{\mathrm{ST}}=$ 0.06, Kingston 1993), but were much higher at larger spatial scales (Mean $\mathrm{F}_{\mathrm{ST}}=0.25,0.6$, and 0.57 for stream, subcatchment, and catchment scales, respectively. See Hughes et al. 1995). This is clearly not the case for Tasiagma and, although some significant differences among streams were recorded, the low within-subcatchment $\mathrm{F}_{\mathrm{ST}}$ values suggest that dispersal of Tasiagma is high. A similar and more striking pattern is also apparent in the other 2 insect species (Fig. 1).

The low $\mathrm{F}_{\mathrm{ST}}$ values at the subcatchment and stream scales would be expected if adult (presumably aerial) dispersal is high and maintains gene flow. Of the several possible explanations for the unusual pattern of higher (and significant) levels of differentiation at smaller spatial scales, Schmidt et al. (1995) concluded that it was most likely the result of 2 factors: 1) individuals are the offspring of only a few matings (i.e. oviposition is patchy); and 2) movement instream is limited. 


\section{Genetic evidence of patchy oviposition and limited in-stream movement}

If stream larvae sampled at the reach scale are the product of a few matings and if movement between reaches is limited, several predictions can be made about the genetic structure of populations:

1) Populations at the reach scale may not always be in Hardy-Weinberg Equilibrium and significant departures from equilibrium will be random across sites and loci.

2) Patterns of genetic differentiation between reaches will differ across loci.

3) Patterns of genetic differentiation between reaches within stream will not necessarily be a function of geographic distance.

4) Patterns of genetic differentiation (1-3 above) will differ among sampling times, provided different cohorts are sampled on each occasion.

We have tested these predictions in our recent work on the genetic structure of populations of Tasiagma and Baetis in the Conondale Range, and the preliminary findings are summarised below.

\section{Departures from Hardy-Weinberg equilibrium are random}

Departures from Hardy-Weinberg Equilibrium imply that samples are not representative of a randomly breeding population. If such departures are due to outcomes of only a few matings, then the departures will occur by chance across sites and loci. For the 6 variable loci examined for Baetis in 1994 at 19 sites, 28 of the 114 tests showed significant departures from Hardy-Weinberg equilibrium. The significant values were spread across all loci and at 14 of the 19 sites. The distribution of Hardy-Weinberg deviations fitted a Poisson distribution, as would be expected from a random distribution of numbers of deviations across sites and loci. A similar random pattern was observed in Tasiagma, with 5 of the 32 tests (4 loci examined at 4 sites and 2 times) showing significant departures from that expected.

\section{Patterns of differentiation differ among loci}

$\mathrm{F}_{\mathrm{ST}}$ values for Baetis show no obvious pattern among sites or loci (Table 1). For example, sig-
TABLE 1. $F_{S T}$ values within 4 streams in the Conondale Range for Baetis larvae $\left({ }^{* * *} p<0.001,{ }^{* *} p<\right.$ $0.01,{ }^{*} p<0.05$, n.s. not significant).

\begin{tabular}{lllll}
\hline \hline $\begin{array}{c}\text { Vari- } \\
\text { able }\end{array}$ & $\begin{array}{c}\text { Booloumba } \\
\text { loci }\end{array}$ & $\begin{array}{c}\text { Bundaroo } \\
\text { Creek }\end{array}$ & $\begin{array}{c}\text { Peters } \\
\text { Creek }\end{array}$ & \multicolumn{1}{c}{$\begin{array}{c}\text { Stony } \\
\text { Creek }\end{array}$} \\
\hline$P g i$ & $0.000^{\text {n.s. }}$ & $0.012^{*}$ & $0.000^{\text {n.s }}$ & $0.000^{\text {n.s. }}$ \\
$P g m$ & $0.000^{\text {n.s. }}$ & $0.000^{\text {ns. }}$ & $0.102^{* * *}$ & $0.007^{\text {n.s. }}$ \\
$M p i$ & $0.187^{* * *}$ & $0.045^{* *}$ & $0.223^{* * *}$ & $0.129^{* * *}$ \\
Est & $0.030^{* *}$ & $0.048^{* *}$ & $0.005^{\text {n.s. }}$ & $0.023^{*}$ \\
$P e p B$ & $0.282^{* * *}$ & $0.181^{* * *}$ & $0.173^{* * *}$ & $0.007^{\text {n.s. }}$ \\
$P e p C$ & $0.014^{*}$ & $0.009^{*}$ & $0.005^{\text {n.s. }}$ & $0.008^{\text {n.s. }}$ \\
Amy & $0.002^{\text {n.s. }}$ & $0.004^{\text {ns. }}$ & $0.018^{*}$ & $0.021^{*}$ \\
\hline
\end{tabular}

nificant differentiation at the PepB locus was recorded among sites within Booloumba, Bundaroo and Peters creeks but not at Stony Creek. Similarly, significant differentiation was recorded at the Pgm locus within Peters Creek, but no differentiation was seen within Bundaroo Creek and Booloumba Creek, which are in the same subcatchment. It is unlikely that such differences among sites within a stream are due to differential selection because of the small distances involved and the apparent similarity in the physical and chemical habitat.

\section{Genetic differentiation is not necessarily a function of geographic distance}

Comparisons of the genetic structure of populations of Baetis and Tasiagma among reaches within-stream do not always show a clear relationship between genetic distance and geographic distance. A simple way to express this is to compare the proportion of comparisons of genetic distance (for each locus and stream) where either adjacent sites or non-adjacent sites were the most similar. If there was at least some movement within stream, then closest sites should be most similar. (Note: there were insufficient data points for a more detailed analysis, e.g., Mantel's test). For Tasiagma, only 4 of the 8 comparisons showed adjacent sites to be most similar. In contrast, 19 of the 20 comparisons for Baetis showed adjacent sites to be most similar. Given the difference in apparent mobility of the actively swimming Baetis larvae and the relatively sedentary sand-cased larvae of Tasiagma, this result is perhaps not surprising. Baetis larvae must be capable of movement among reach- 
TABLE 2. $F_{S T}$ values within Bundaroo Creek in the Conondale Range for Tasiagma larvae sampled in Au-

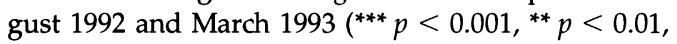
${ }^{*} p<0.05,{ }^{\text {n.s }}$ not significant).

\begin{tabular}{ccc}
\hline \hline $\begin{array}{c}\text { Variable } \\
\text { loci }\end{array}$ & August 1992 & March 1993 \\
\hline$P g i$ & $0.005^{\text {n.s. }}$ & $0.047^{* * *}$ \\
$P g m$ & $0.045^{* * *}$ & $0.007^{\text {n s. }}$ \\
PepC & $0.015^{* *}$ & $0.031^{\text {** }}$ \\
Acon & $0.027^{* * *}$ & $0.007^{\text {n }}$ \\
\hline
\end{tabular}

es, but the significant $\mathrm{F}_{\mathrm{ST}}$ values imply that such movement is not high (Table 1).

\section{Patterns of genetic differentiation are not} consistent between times

Analysis of the genetic structure of populations of the above taxa within and between streams on subsequent sampling occasions has revealed that the patterns observed at the reach scale are not consistent. For example, the $\mathrm{F}_{\mathrm{ST}}$ values for Tasiagma were significant at Pgm, PepC, and Acon in August 1992, whereas Pgi and PepC were significant in March 1993 (Table 2). Furthermore, the overall pattern of similarity of genetic distance among the 4 sites within Bundaroo Creek differed between sampling occasions.

\section{Conclusions}

The wide geographic distributions of species and the small differences in genetic structure at large spatial scales (stream/subcatchment) suggest that adult flight is the major mechanism of dispersal for stream insects in the Conondale Range. Similar large-scale patterns of genetic structure have been reported for species of aquatic insects in other stream systems (Sweeney et al. 1986, 1987, Jackson and Resh 1992). In contrast, larvae (and fully aquatic adults of some species) apparently move very little within stream, resulting in significant genetic differentiation at the reach scale. Furthermore, other aspects of the genetic data suggest that larvae at the reach scale are likely to be the offspring of only a few matings.

\section{Additional evidence of limited in-stream movement and patchy oviposition}

\section{Movement within stream}

Other evidence supports the view that movement of aquatic invertebrates within streams of the Conondale Range is limited. The physical nature of the streams provides many natural barriers to aquatic dispersal. For much of the year, streams are reduced to a string of discrete pools, often interconnected by rock chutes and small waterfalls.

Recolonisation by the more sedentary algal grazers, such as Tasiagma and the other sand cased caddis, is known to be slow after disturbance from high discharge events, and apparently is the result of recruitment rather than movement of displaced larvae (Mosisch 1995, Bunn unpublished data). Drift rates measured on several occasions during the study period were also very low, often much less than 5 individuals $\mathrm{m}^{-3} \mathrm{~h}^{-1}$, and the drift fauna consisted largely of chironomid and simuliid larvae (Kerby et al. 1995).

The genetic evidence that in-stream movement by Paratya is limited has been supported by a recent translocation experiment using genetically 'tagged' individuals. Hancock (1996) moved approximately 9500 shrimps from a single large pool in Kilcoy Creek to a similar pool in Branch Creek, and approximately 6500 from Branch to Kilcoy. Samples of shrimps were taken at regular intervals from the release point and at pools upstream and downstream, and frozen for electrophoretic analysis. Shrimps from these 2 streams could be distinguished by unique alleles at 4 genetic loci. Little movement of marked animals was observed, and most of this was in an upstream direction. After 1 year, marked adults had moved $123 \mathrm{~m}$ upstream at the Kilcoy Creek site where they formed about $1 \%$ of the pool population, and $232 \mathrm{~m}$ at the Branch Creek site where they formed approximately $8 \%$ of the pool population. The latter individuals had scaled several small waterfalls with a combined altitude of $8 \mathrm{~m}$. Throughout the year of study, the proportion of marked individuals in the release pools remained relatively constant from day zero (Hancock 1996).

\section{Larvae the offspring of a few adults?}

Can a few matings and the chance oviposition by a few females account for the number of lar- 
TABLE 3. Estimates of population size of 4 th- and 5th-instar Tasiagma larvae from study reaches at 4 rainforest streams in the Conondale Range, on 21 July 1992.

\begin{tabular}{lccccc}
\hline \hline \multicolumn{1}{c}{ Site } & $\begin{array}{c}\text { Density } \\
\text { 4th/5th } \\
\text { instars }\left(/ \mathrm{m}^{2}\right)\end{array}$ & $\begin{array}{c}\text { Area of } \\
\text { larval } \\
\text { habitat }\left(\mathrm{m}^{2}\right)\end{array}$ & $\begin{array}{c}\text { Total } \\
\text { 4th/5th } \\
\text { instars }\end{array}$ & $\begin{array}{c}\text { Total } \\
\text { eggs } \\
\text { required }\end{array}$ & $\begin{array}{c}\text { Total } \\
\text { females } \\
\text { required }^{\text {b }}\end{array}$ \\
\hline Stony Ck & 2.4 & 50 & 122 & 2430 & 8 \\
Branch Ck & 6.0 & 30 & 180 & 3600 & 12 \\
Booloumba Ck & 2.5 & 30 & 75 & 1500 & 5 \\
Bundaroo Ck & 2.0 & 20 & 40 & 800 & 3 \\
\hline
\end{tabular}

a The number of eggs required to achieve observed densities was estimated using an assumed mortality of eggs and young larvae of $95 \%$

$\mathrm{b}$ The number of females required to account for the estimated egg numbers was determined using an average fecundity of 300

vae observed at any reach? We used density and size-frequency data for Tasiagma from 4 streams in July 1992 to estimate the total number of 4thand 5th-instar larvae in the sample reaches. These data were obtained immediately prior to the August samples taken at Bundaroo Creek for electrophoretic analysis (see Table 2). Larger instars of Tasiagma are found predominantly on boulders and generally a few $\mathrm{cm}$ below (and often above) the water surface (Negus 1995). On this occasion, we estimated the total area of habitat occupied by Tasiagma larvae to be approximately $20-50 \mathrm{~m}^{2}$ (Table 3 ). Assuming a high mortality $(95 \%)$ of eggs and young larvae, similar to that of other cased caddis (Cummins and Wilzbach 1988), we estimated the number of eggs that were needed to account for the observed densities of 4th- and 5th-instar larvae. Using an average fecundity ( $\pm 1 \mathrm{SE}, n=4)$ of adults caught at the sites of $300 \pm 29$, we estimated that between 3 and 12 females would be required to account for the observed larval densities (Table 3).

Although these estimates are crude, they illustrate that the observed densities of Tasiagma larvae at the study sites can be accounted for by oviposition by only a few females. In the case of Bundaroo Creek, where the detailed between-reach comparisons were made, only 3 females would have sufficed (Table 3 ). The abundance of Baetis larvae in these streams is much higher than that of Tasiagma. For example, $\mathrm{Ne}-$ gus (1995) recorded mean densities of Baetis on boulder habitats of $90-300$ larvae $/ \mathrm{m}^{2}$, with a maximum density of $2000 / \mathrm{m}^{2}$. However, high larval densities could still result from the offspring of a small number of females if fecundity is high. Wilzbach and Cummins (1989) have also raised the possibility that, because aquatic insects typically produce $200-2000$ eggs, only a few randomly flying adult females would be required to re-populate a section of stream. Williams and Williams (1993) also proposed that benthic populations of insect larvae in Welsh streams were maintained through oviposition by females in the vicinity of their emergence sites. We have recorded very few adult stream insects in monthly light traps or by other techniques in the Conondale Range, and emergence trap collections and larval life history patterns indicate that the study species do not have synchronised mass emergence of adults.

\section{Is recruitment likely to be important in all streams?}

The important role of dispersal and recruitment is not new to ecology. The "supply" of recruits is a well known process in marine systems, and can be of over-riding importance in determining the structure and dynamics of communities (Underwood and Fairweather 1989, Sale 1990). The major difference in these rainforest streams is that the dispersing "propagules" are adults and not larvae, as is the case in marine systems and is claimed to be the case in other stream systems (Palmer et al. 1996).

Would we expect to find similar patterns of dispersal and recruitment in other stream systems? Certainly, there are some features of the rainforest streams we have studied that are more likely to give rise to the strong influence of recruitment effects. We would predict that the patterns described here are unlikely to occur in streams where larval development is synchronous and leads to mass emergence (and high 
numbers) of adults. In less predictable climates, a feature of southeast Queensland and many other parts of Australia, larval life cycles are asynchronous and adult emergence is aseasonal (Lake et al. 1986, Bunn 1988, Bunn and Davies 1990). Aseasonal emergence is likely to give rise to only a few matings at any time and increase the role of chance in oviposition at a particular reach. Furthermore, if only a few females oviposit at the same time, the resulting densities of developing larvae will not be high. Hynes (1975) proposed that behavioural drift in tropical streams may be less marked than in temperate streams because benthic populations are never large. The low drift rates observed in subtropical streams of the Conondale Range may be a function of the lack of density-dependent dispersal of larvae that would be expected if numerous hatchings occurred in a short time span (Waters 1965).

A second feature of the streams described here that may contribute to limited dispersal is that flow is very low for most of the year and much of the aquatic habitat consists of interconnected pools. Limited in-stream movement of aquatic invertebrates may be expected in similar bed-rock controlled, high gradient streams with obvious physical barriers to dispersal and prolonged periods of low flow.

Are these streams such a special case? Certainly most of the world literature on streams deals with temperate forest systems, but this does not necessarily mean that most streams are like those in North America and Europe. Similar recruitment processes to those described here may be important in stream systems in other less-studied parts of the world. For example, species turnover between years in some arctic and subarctic streams (Miller and Stout 1989) and cold desert spring-streams (Cushing and Gaines 1989) is very high, and the process of species extinctions and immigrations is thought to be stochastic.

\section{Conclusions}

The influence of population-level processes, such as dispersal and recruitment, on the structure and dynamics of stream communities has been down-played in the past. We propose that dispersal capability and the stochastic effects of recruitment can be key determinants of observed spatial and temporal variation in com- munity structure in some streams. These factors not only can influence the rate of recovery of populations after large scale disturbance but also can lead to erratic patterns of recruitment in space and time.

\section{Acknowledgements}

Many people have contributed to the collection of the data discussed in this paper. In particular, we thank Cath Cleary, Marty Hancock, Dave Hurwood, Megan Kempster, Bernadette Kerby, Mark Kingston, Lisa Gallagher, Thorsten Mosisch, Peter Negus, Sonja Schmidt, and especially Chris Marshall. We also thank other participants in the symposium on New Concepts in Stream Ecology, held at the Savannah River Ecology Laboratory in October 1995, for their stimulating discussion and ideas. The paper has been considerably improved by comments from Joseph Culp, Rosemary Mackay, and two anonymous referees. Much of the research described here was supported by the Australian Research Council and the Griffith University Research Grants Scheme.

\section{Literature Cited}

ANHOLT, B. R. 1995. Density dependence resolves the stream drift paradox. Ecology 76:2235-2239.

Australian Bureau OF Meteorology. 1983. The climate of Brisbane, Queensland. Capital City Series. Australian Government Public Service, Canberra.

Benson, L. J., and R. G. Pearson. 1987. Drift and upstream movement in Yuccabine Creek, an Australian tropical stream. Hydrobiologia 153:225239.

Boulton, A. J., G. M. Spangaro, and P. S. Lake. 1988. Macroinvertebrate distribution and recolonization on stones subjected to varying degrees of disturbance: an experimental approach. Archiv für Hydrobiologie 113:551-576.

BUNN, S. E. 1988. Life histories of some benthic invertebrates from streams of the northern jarrah forest. Australian Journal of Marine and Freshwater Research 39:785-804.

BunN, S. E., AND P. M. DAvies. 1990. Why is the stream fauna of south-western Australia so impoverished? Hydrobiologia 194:169-176.

Cummins, K. W., AND M. A. WilzBach. 1988. Do pathogens regulate stream invertebrate populations? Verhandlungen der Internationalen Vereinigung für theoretische und angewandte Limnologie 23:1232-1243. 
Cushing, C. E., AND W. L. GaINEs. 1989. Thoughts on recolonization of endorheic cold desert springstreams. Journal of the North American Benthological Society 8:277-287.

Czechura, G. V. 1991. The Blackall-Conondale Ranges: frogs, reptiles and fauna conservation. Pages 311-324 in G. Werren and P. Kershaw (editors). The rainforest legacy. Volume 2 -flora and fauna of the rainforest. Australian Government Publishing Service, Canberra.

ERMAN, N. A. 1986. Movements of self-marked caddisfly larvae, Chyranda centralis (Trichoptera, Limnephilidae) in a Sierran spring stream, California, U.S.A. Freshwater Biology 16:455-464.

FrEILICH, J. E. 1991. Movement patterns and ecology of Pteronarcys nymphs (Plecoptera): observations of marked individuals in a Rocky Mountain stream. Freshwater Biology 25:379-394.

HANCOCK, M. A. 1996. Population dynamics and life history of Paratya australiensis Kemp, 1917 (Decapoda: Atyidae) in upland rainforest streams, southeast Queensland, Australia. PhD Thesis, Faculty of Environmental Sciences, Griffith University, Queensland.

Hershey, A. E., J. Pastor, B. J. Peterson, and G. W. KLING. 1993. Stable isotopes resolve the drift paradox for Baetis mayflies in an arctic river. Ecology 74:2315-2325.

Hughes, J. M., S. E. BunN, D. HuRwoOd, AND M. KINGSTON. 1995. Genetic differentiation of populations of Paratya australiensis (Decapoda: Atyidae) in rainforest streams in south-east Queensland. Journal of the North American Benthological Society 14:158-173.

Hughes, J. M., S. E. BunN, D. A. Hurwood, S. ChOY, AND R. G. PEARSON. 1996. Genetic differentiation among populations of Caridina zebra (Decapoda: Atyidae) in tropical rainforest streams, northern Australia. Freshwater Biology 36:289-296.

HyNES, H. B. N. 1970. The ecology of running waters. Liverpool University Press, Liverpool, UK.

HYNES, J. D. 1975. Downstream drift of invertebrates in a river in southern Ghana. Freshwater Biology 5:515-532.

JACKSON, J. K., AND V. H. RESH. 1992. Variation in genetic structure among populations of the caddisfly Helicopsyche borealis from three streams in northern California, U.S.A. Freshwater Biology 27:29-42.

Kerby, B. M., S. E. BunN, AND J. M. Hughes. 1995. Factors influencing invertebrate drift in rainforest streams in south-east Queensland. Marine and Freshwater Research 46:1101-1108.

KINGSTON, M. B. 1993. Some aspects of gene flow in stream and river ecosystems. Honours Thesis, Faculty of Environmental Sciences, Griffith University, Queensland, Australia.

LAKE, P. S., L. A. BARMUTA, A. J. BOUlton, I. C. CAMP-
BELL, AND R. M. ST. ClaIR. 1986. Australian streams and Northern Hemisphere stream ecology: comparisons and problems. Proceedings of the Ecological Society of Australia 14:61-82.

LAKE, P. S., T. J. DOEG, AND R. MARChANT. 1989. Effects of multiple disturbance on macroinvertebrate communities in the Acheron River, Victoria. Australian Journal of Ecology 14:507-514.

LEE, C. L., AND D. R. FIELDER. 1979. A mass migration of the freshwater prawn Macrobrachium australiense Holthuis, 1950 (Decapoda, Palaemonidae). Crustaceana 37:219-222.

MACKAY, R. J. 1992. Colonization by lotic macroinvertebrates: a review of processes and patterns. Canadian Journal of Fisheries and Aquatic Sciences 49:617-628.

MefFe, G. K., AND R. C. VRIJENhoek. 1988. Conservation genetics in the management of desert fishes. Conservation Biology 2:157-167.

MilleR, M. C., AND J. R. STOUT. 1989. Variability of macroinvertebrate community composition in an arctic and subarctic stream. Hydrobiologia 172: 111-127.

Minshall, G. W., AND R. C. Petersen. 1985. Towards a theory of macroinvertebrate community structure in stream ecosystems. Archiv für Hydrobiologie 104:49-76.

Mosisch, T. 1995. The effects of biological and physical disturbance on rainforest stream algal communities. PhD Thesis, Faculty of Environmental Sciences, Griffith University, Queensland, Australia.

Mosisch, T., AND S. E. BUNN. 1997. Temporal patterns of rainforest stream epilithic algae in relation to flow-related disturbance. Aquatic Botany (in press).

MÚLLER, K. 1982. The colonization cycle of freshwater insects. Oecologia 52:202-207.

Negus, P. M. 1995. The distribution of grazing invertebrates and the factors causing this distribution in Stony Creek, a subtropical rainforest stream in south-east Queensland. Honours Thesis, Faculty of Environmental Sciences, Griffith University, Queensland, Australia.

Palmer, M. A., J. D. Allan, ANd C. A. Butman. 1996. Dispersal as a regional process affecting the local dynamics of marine and stream benthic invertebrates. Trends in Ecology and Evolution 11:322326.

Pusey, B. J., A. H. Arthington, AND M. G. Read. 1993. Spatial and temporal variation in fish assemblage structure in the Mary River, south-eastern Queensland: the influence of habitat structure. Environmental Biology of Fishes 37:355-380.

REICE, S. R. 1985. Disturbance and the maintenance of diversity in stream communities. Oecologia 67: 90-97.

Resh, V. H., A. V. Brown, A. P. Covich, M. E. Gurtz, 
H. W. Li, G. W. Minshall, S. R. Reice, A. L. ShelDON, J. B. Wallace, AND R. Wissmar. 1988. The role of disturbance in stream ecology. Journal of the North American Benthological Society 7:433455.

RYAN, P. A., AND S. C. CHOY. 1990. Observations of mass upstream migration of Varuna litterata (Fabricius) megalopae (Decapoda, Brachyura, Grapsidae) in Fiji. Crustaceana 58:237-249.

SALE, P. F. 1990. Recruitment of marine species: Is the bandwagon rolling in the right direction? Trends in Ecology and Evolution 5:25-27.

SCHMIDT, S., J. M. HugheS, AND S. E. BunN. 1995. Gene flow among conspecific populations of Baetis (Ephemeroptera): adult flight and larval drift. Journal of the North American Benthological Society 14:147-157.

SLATKIN, M. 1985. Gene flow in natural populations. Annual Review of Ecology and Systematics 16: 393-430.

SWEeney, B. W., D. H. FunK, AND R. L. VANNOTE. 1986. Population genetic structure of two mayflies (Ephemerella subvaria, Eurylophella verisimilis) in the Delaware River drainage basin. Journal of the North American Benthological Society 5:253262.

SWEeney, B. W., D. H. FunK, AND R. L. VANnOte. 1987. Genetic variation in stream mayfly (Insecta: Ephemeroptera) populations in eastern North America. Annals of the Entomological Society of America 80:600-612.

UNDERWOOD, A. J., AND P. G. FAIRWEATHER. 1989.
Supply-side ecology and benthic marine assemblages. Trends in Ecology and Evolution 4:16-20.

WALLACE, J. B. 1990. Recovery of lotic macroinvertebrate communities from disturbance. Environmental Management 15:605-620.

WAPLES, R. S. 1987. A multispecies approach to the analysis of gene flow in marine shore fishes. Evolution 41:385-400.

WATERS, T. F. 1965. Interpretation of invertebrate drift in streams. Ecology 46:327-334.

Williams, D. D., AND H. B. N. HyNes. 1976. The recolonization mechanisms of stream benthos. Oikos 27:265-272.

Williams, D. D., AND N. E. Williams. 1993. The upstream/downstream movement paradox of lotic invertebrates: quantitative evidence from a Welsh mountain stream. Freshwater Biology 30:199-218.

Williams, W. D. 1977. Some aspects of the life history of Paratya australiensis (Crustacea: Decapoda: Atyidae). Australian Journal of Marine and Freshwater Research 28:403-415.

WilzBACH, M. A., AND K. W. CUMmINS. 1989. An assessment of short-term depletion of stream macroinvertebrate benthos by drift. Hydrobiologia 185:29-39.

ZERA, A. J. 1987. Temperature dependent kinetic variation among phosphoglucose isomerase allozymes from the wing-polymorphic water strider, Linoporus caniculatus. Molecular Biology and Evolution 4:266-285.

Received: 2 July 1996

Accepted: 5 February 1997 